\title{
Crop coefficient and water requirement of prickly pear in the Agreste region of Alagoas state, Brazil
}

\author{
Jesiele S. Divincula ${ }^{1}$, Cinara B. da Silva ${ }^{2}$, Marcio A. L. dos Santos ${ }^{2}$, Daniella P. dos Santos ${ }^{1} \&$ \\ Luan W. dos Santos ${ }^{3}$ \\ ${ }^{1}$ Universidade Federal Rural de Pernambuco/Departamento de Engenharia Agrícola. Recife, PE, Brasil. E-mail: jeeh.divincula@gmail.com (Corresponding \\ author) - ORCID: 0000-0001-9962-6940; daniellapsantos@hotmail.com - ORCID: 0000-0002-4450-0141 \\ ${ }^{2}$ Universidade Federal de Alagoas. Arapiraca, AL, Brasil. E-mail: cinara_cbs@hotmail.com - ORCID: 0000-0003-0666-4329; mal.santo@arapiraca.ufal.br - \\ ORCID: 0000-0001-5216-4443 \\ ${ }^{3}$ Universidade Federal de Sergipe. São Cristóvão, SE, Brasil. E-mail: luan_wamberg@hotmail.com - ORCID: 0000-0001-7549-0823
}

\begin{abstract}
Prickly pear cultivation has played an important role in the Brazilian livestock farming, being used as forage for animals in the Northeast region, especially during the drying season, because it is an excellent source of water. Thus, the objective of this study was to estimate the crop coefficient and water requirement of prickly pear in the Agreste region of Alagoas state, Brazil. Prickly pear crop evapotranspiration (ETc) was determined using five drainage lysimeters, made of polyethylene with dimensions of $0.35 \times 0.40 \mathrm{~m}$ (side and depth). Four soil layers were separated and put into the lysimeters in the opposite sequence, in order to maintain it as close as possible to the initial soil structure. The reference evapotranspiration (ETo) was estimated by the Penman-Monteith, Hargreaves-Samani and FAO-Radiation methods, using climatic data from the meteorological station of the Instituto Nacional de Meteorologia (INMET) in the city of Arapiraca, AL, Brazil. Crop coefficient $(\mathrm{kc})$ was calculated by the ratio between ETc and ETo. The average kc obtained was 0.72, 0.84 and 0.48 for the Penman-Monteith, Hargreaves-Samani and FAO-Radiation methods, respectively. Keeping the soil under field capacity during the experimental period, the total crop evapotranspiration was $637.84 \mathrm{~mm}$, with daily value equal to $4.22 \mathrm{~mm} \mathrm{~d}^{-1}$.
\end{abstract}

Key words: Opuntia ficus-indica L., evapotranspiration, lysimeters

\section{Coeficiente de cultivo e necessidade hídrica da palma forrageira no agreste de Alagoas}

RESUMO: O cultivo da palma forrageira tem exercido papel importante na pecuária brasileira, sendo utilizada como forragem para os animais na região Nordeste, especialmente na época de escassez de chuvas, por ser uma excelente fonte de água. Deste modo, objetivou-se com o esse trabalho estimar o coeficiente de cultivo e a necessidade hídrica da palma forrageira no agreste de Alagoas. A evapotranspiração da cultura (ETc) da palma forrageira foi determinada utilizando cinco lisímetros de drenagem, construídos de material polietileno com dimensões de 0,35 x 0,40 m (lado e profundidade). Foram separadas quatro camadas do solo, sendo colocadas nos lisímetros de maneira inversa, a fim de manter o mais próximo da estrutura inicial do solo. Já a evapotranspiração de referência (ETo) foi estimada pelos métodos de Penman-Monteith, Hargreaves-Samani e FAO-Radiação, utilizando dados climáticos da estação meteorológica do Instituto Nacional de Meteorologia (INMET) da cidade de Arapiraca, AL, Brazil. O coeficiente de cultivo (kc) foi calculado pela razão entre a ETc e a ETo. O kc médio obtido foi de 0,72; 0,84 e 0,48 para os métodos de Penman-Monteith, HargreavesSamani e FAO-Radiação, respectivamente. Mantendo o solo sob capacidade de campo durante todo período experimental, a evapotranspiração total da cultura foi de $637,84 \mathrm{~mm}$, com valor diário de 4,22 $\mathrm{mm} \mathrm{dia}^{-1}$.

Palavras-chave: Opuntia ficus-indica L., evapotranspiração, lisímetros 


\section{INTRODUCTION}

Prickly pear belongs to the Cactaceae family, which has as its main characteristic the modification in the photosynthetic process, called the Crassulacean Acid Metabolism (CAM). In addition, it has peculiar characteristics, such as the absence of leaves and photosynthetic apparatus located in the cladodes (Arruda et al., 2005). Despite its high potential as food for human, cosmetic industry, biofuel production and others, prickly pear has been basically used as animal feed, especially during periods of long drought, when there is a shortage of pasture (Bezerra et al., 2014).

Pereira et al. (2015) emphasize that, in regions where water availability is insufficient to achieve the ideal conditions for prickly pear cultivation, the use of irrigation is recommend, and evapotranspiration is an important parameter to determine crop water needs (Souza et al., 2011). Evapotranspiration can be measured either directly, using lysimeters, or indirectly, through mathematical models (Alves et al., 2017).

Lysimeters are buried waterproof containers containing the soil representative of the region cultivated with a crop to be studied (Miranda et al., 2016; Alves et al., 2017). Crop coefficient $(\mathrm{kc})$ is the ratio between crop evapotranspiration (ETc) and reference evapotranspiration $\left(\mathrm{ET}_{\mathrm{O}}\right)$, being determined for each phenological stage of the crop (Allen et al., 1998).

Therefore, the present study aims to estimate the water requirement and crop coefficient of prickly pear in Arapiraca, in the Agreste region of Alagoas state, Brazil.

\section{Material AND Methods}

The experiment was conducted for 152 days, in the period from December 9, 2014, to May 10, 2015, in the experimental area of the Grupo de Pesquisa, Extensão e Inovação Tecnológica em Manejo de Água para Irrigação (Grupo Irriga), on the Campus of Arapiraca of the Universidade Federal de Alagoas. It is located in an area of transition between Zona da Mata and Sertão Alagoano, municipality of Arapiraca, AL, Brazil, at geodetic coordinates $9^{\circ} 45^{\prime} 58^{\prime \prime} \mathrm{S}$ and $35^{\circ} 38^{\prime} 58^{\prime \prime} \mathrm{W}$, and altitude of $325 \mathrm{~m}$.

The climate of the region is classified as tropical 'As', with dry summer seasons according to Köppen's classification. The soil of the experimental area is classified as Ultisol. According to Xavier \& Dornellas (2010), the annual precipitation of the region is approximately $854 \mathrm{~mm}$, and the rains are irregularly distributed throughout the year, with rainy season starting at mid-May and extending until mid-August.

Prickly pear ETc was determined using five drainage lysimeters constructed of square polyethylene material with dimensions of $0.35 \times 0.40 \mathrm{~m}$ (side and depth). For setting up the lysimeters, pits with depth, width and length of $0.50 \mathrm{~cm}$ were excavated, and the soil layers $(0-0.10 ; 0.10-0.20 ; 0.20-0.30 ; 0.30$ $0.40 \mathrm{~m}$ ) were separated for subsequent filling of the lysimeter, which first received a $10-\mathrm{cm}$-thick layer, corresponding to the 0.40-0.50 m layer, of sand and crushed stone to facilitate the drainage.

The prickly pear cultivation area including the five lysimeters installed was $5.2 \mathrm{~m}^{2}$, with three rows of $2.6 \mathrm{~m}$ in length spaced by $1 \mathrm{~m}$ and dense planting with $0.10 \mathrm{~m}$ spacing between plants. For crop planting, 78 cladodes were selected and distributed along three planting rows, 4 cladodes for each lysimeter. A drip irrigation system with flow rate of $1.0 \mathrm{~L} \mathrm{~h}^{-1}$ was used to irrigate the prickly pear cultivation area and provide water for the lysimeters.

The lysimeters were saturated for $24 \mathrm{~h}$ and, immediately after, the drains were opened for draining the free water and thus for the soil to reach field capacity. After that, the cladodes were planted and the first water application was performed in the lysimeter. Readings of the water drained from the lysimeters and calculation of the water applied to the lysimeters were performed daily, using Eq. 1, thus obtaining the daily ETc of the prickly pear crop, as described by Alves et al. (2017).

$$
\mathrm{ETc}=\mathrm{P}+\frac{\mathrm{La}}{\mathrm{A}}-\frac{\mathrm{Ld}}{\mathrm{A}}
$$

where:

ETc - crop evapotranspiration, $\mathrm{mm}$;

$\mathrm{P}$ - precipitation, $\mathrm{mm}$;

La - water depth applied by irrigation, L;

Ld - water depth drained from the lysimeter, L; and,

A - lysimeter area, $\mathrm{m}^{2}$.

ETo estimation was performed by the methods of PenmanMonteith, proposed by Allen et al. (1998), Hargreaves-Samani, presented by Pereira et al. (1997) and FAO-Radiation, described by Doorenbos \& Pruitt (1975), using the data from the meteorological station of the automatic station of the Instituto Nacional de Meteorologia (INMET) of the Arapiraca city, AL, Brazil. Precipitation values were collected from a rain gauge installed in the experimental area.

ETo values $\left(\mathrm{mm} \mathrm{d}^{-1}\right)$ estimated by the methods of Hargreaves-Samani and FAO-Radiation were correlated by the Penman-Monteith standard method using the analysis of correlation, linear regression, coefficient of variation (CV) and F-statistic, generated by the statistical software R. This correlation was based on statistical indicators in order to observe the accuracy given by the correlation coefficient (r), which is associated with the deviation between estimated and measured values, indicating the degree of dispersion of the obtained data in relation to the mean.

The standard error of the estimate (SEE), adjusted standard error of the estimate $\left(\mathrm{SEE}_{\mathrm{adj}}\right)$, coefficients of fitting of linear equations with their respective coefficients of determination $\left(\mathrm{R}^{2}\right)$ were the criteria used for ETo comparison and analysis (Jensen et al., 1995). For the accuracy of the empirical methods, the performance index (c) was determined, calculated by the product of the Pearson's correlation coefficient ( $r$ ) and the index agreement (d) of Willmott et al. (1985).

The values of $r$ and $c$ found were classified according to Hopkins' methodology and according to Camargo \& Sentelhas (1997), (Table 1).

After the collection of daily ETc data, obtained through the drainage lysimeters, and ETo data, obtained through the empirical equations for each method, kc was determined for each phenological stage of the prickly pear crop. The crop 
Table 1. Classification of the values of Pearson's correlation coefficient (r) and performance index (c), determined by Willmott et al. (1985)

\begin{tabular}{|cc|}
\hline Correlation coefificient $(\mathbf{r})$ & Classification \\
\hline $0-0.1$ & Very low \\
$0.1-0.3$ & Low \\
$0.3-0.5$ & Moderate \\
$0.5-0.7$ & High \\
$0.7-0.9$ & Very high \\
$0.9-1.0$ & Nearly perfect \\
\hline Performance index (c) & \\
\hline 0.85 & Excellent \\
$0.76-0.85$ & Very good \\
$0.66-0.75$ & Good \\
$0.6-0.65$ & Median \\
$0.51-0.60$ & Tolerable \\
$0.41-0.50$ & Poor \\
$\leq 0.40$ & Very poor \\
\hline
\end{tabular}

Source: Camargo \& Sentelhas (1997); Hopkins (2000)

coefficient $(\mathrm{kc})$ was calculated by the ratio between ETc and ETo (Eq. 2) and calculated for three methods.

$$
\mathrm{kc}=\frac{\mathrm{ETc}}{\mathrm{ETo}}
$$

where:

kc - crop coefficient, dimensionless;

ETc - crop evapotranspiration, $\mathrm{mm} \mathrm{d}^{-1}$; and,

ETo - reference evapotranspiration, $\mathrm{mm} \mathrm{d}^{-1}$.

\section{Results AND Discussion}

Figure 1 shows the ETo values for the Penman-Monteith method, for which the maximum value was $7.44 \mathrm{~mm} \mathrm{~d}^{-1}$, on January 19, and the lowest value was $3.03 \mathrm{~mm} \mathrm{~d}^{-1}$, on March 10. There was a reduction between February 19 and 28, and this was the period with the lowest temperatures. In studies conducted for the Agreste region of Alagoas, Ferreira Júnior et al. (2006) found maximum evapotranspiration of $7.06 \mathrm{~mm}$ $\mathrm{d}^{-1}$ and minimum of $0.75 \mathrm{~mm} \mathrm{~d}^{-1}$, and the maximum value is close to that of the present study. For the Hargreaves-Samani method, the values ranged between 6.25 and $3.42 \mathrm{~mm} \mathrm{~d}^{-1}$. Borges Júnior et al. (2012), working in the microregion of Garanhuns, PE, Brazil, obtained maximum evapotranspiration of $6.30 \mathrm{~mm} \mathrm{~d}^{-1}$, close to that of the present study, and minimum evapotranspiration of $0.40 \mathrm{~mm} \mathrm{~d}^{-1}$.

The FAO-Radiation method showed maximum value of $8.49 \mathrm{~mm} \mathrm{~d}^{-1}$ and minimum value of $2.59 \mathrm{~mm} \mathrm{~d}^{-1}$. Borges Júnior et al. (2012), estimating daily ETo for the conditions of the municipality of Garanhuns, PE, Brazil, found maximum value of $7.0 \mathrm{~mm} \mathrm{~d}^{-1}$ and minimum value of $1.10 \mathrm{~mm}^{-1}$, which are close to those found in the present study.

Figures $2 \mathrm{~A}$ and B present the linear fit of ETo values estimated by the respective methods of Hargreaves-Samani and FAO-Radiation correlated with the Penman-Monteith method (FAO-standard). The correlation of the Hargreaves-Samani method was considered low, with $r=0.6022$, whereas the FAO-Radiation method showed higher correlation, confirmed by the coefficient of determination, $\mathrm{R}^{2}=84.79 \%$.

The angular coefficient of the equation in Figure $2 \mathrm{~A}$ was less than 1 , indicating that the values found in the $\mathrm{X}$-axis $\left[\mathrm{ETo}_{(\mathrm{P}-\mathrm{M})}\right]$ are higher than those found in the Y-axis $\left[\mathrm{ETo}_{(\mathrm{H}-\mathrm{S})}\right]$, demonstrating an underestimation of the ETo values by the Hargreaves-Samani method. On the other hand, in Figure $2 \mathrm{~B}$ the value of the angular coefficient is greater than 1 , demonstrating an overestimation of the values by the FAORadiation method in relation to the values obtained by the Penman-Monteith method. The Table 2 shows low coefficients of determination $\left(\mathrm{R}^{2}=60.22 \%\right)$ and a very high Pearson's correlation coefficient $(\mathrm{r}=0.7760)$ for $\mathrm{ETo}_{(\mathrm{H}-\mathrm{S})}$, indicating that the method is accurate to estimate ETo for the region of study, despite having a low $\mathrm{R}^{2}$. The $\mathrm{ETo}_{(\mathrm{H}-\mathrm{S})}$ had a tolerable performance index $(\mathrm{d}=0.6905$ and $\mathrm{c}=0.5358)$, according to the estimates of ETo obtained in this study. These results corroborate the studies conducted in Ilhéus, BA, Brazil, by Tagliaferre et al. (2010), who found that the Hargreaves-Samani method had the worst performance index, being classified as tolerable. Costa et al. (2017), studying ETo estimation for the city of Palmeira dos Índios, AL, Brazil, through the H-S method, obtained an excellent performance index, differing from the results found in these studies.

In Table 2, it is possible to observe that the FAO-Radiation method had high coefficient of determination $\left(R^{2}=0.8479\right)$ and very high coefficient of correlation $(r=0.9208)$, showing the accuracy of ETo estimation. The performance index of the FAO-Radiation method was very good $(c=0.8705$ and $d$ $=0.9453$ ), with nearly perfect correlation. Similar results for

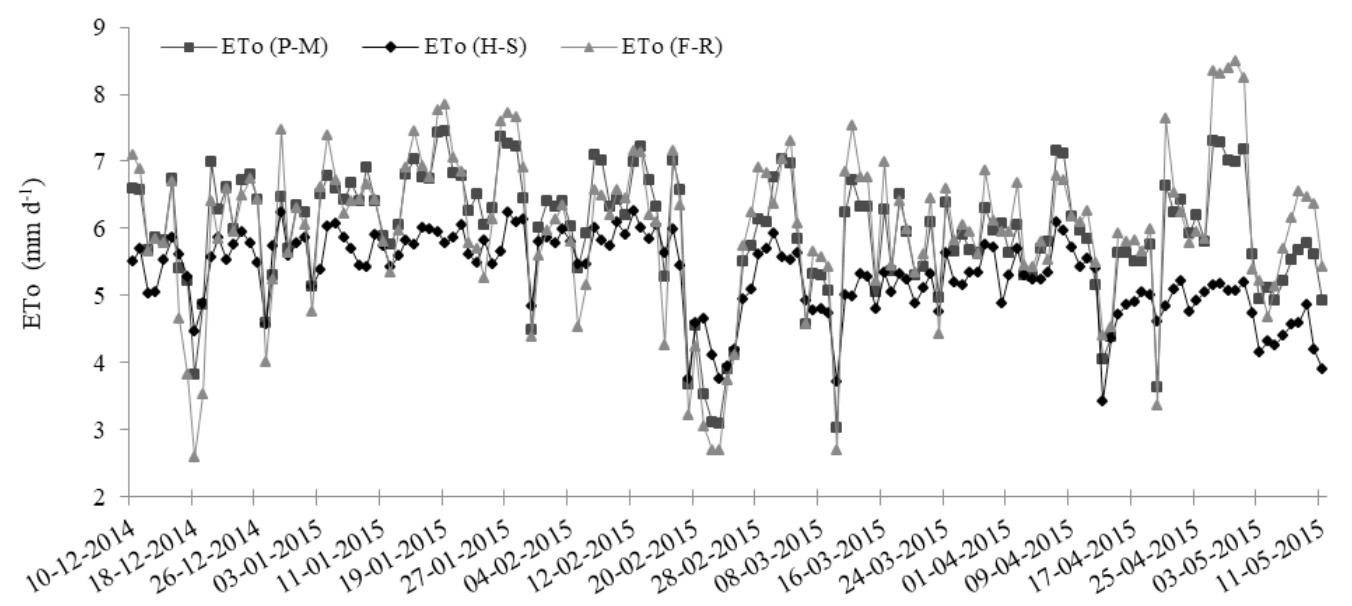

Figure 1. Values of reference evapotranspiration estimated by the Penman-Monteith - P-M, Hargreaves-Samani - H-S and FAORadiation - F-R methods for the municipality of Arapiraca, AL, Brazil, in the period from December 9, 2014 to May 10, 2015 

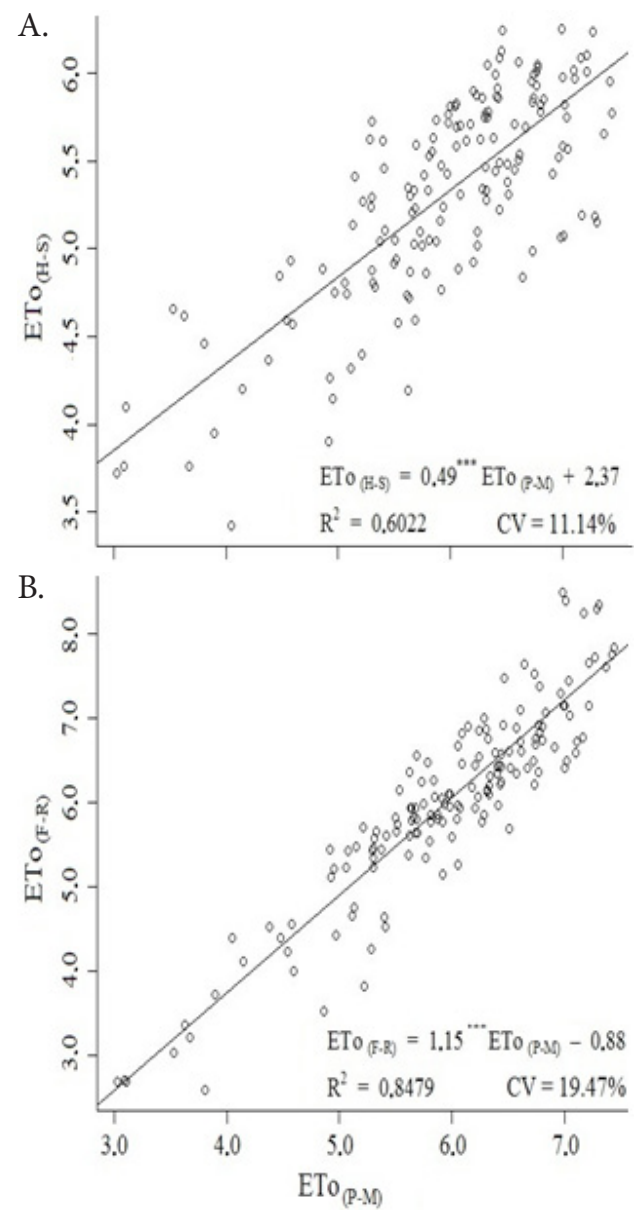

${ }^{* * *}$ Angular and linear coefficients of the linear regression were significant at $\mathrm{p} \leq 0.00$ probability level by test $\mathrm{F}$

Figure 2. Correlation between the reference evapotranspiration obtained by Hargreaves-Samani - H-S (A) and FAO-Radiation - F-R (B) methods and obtained by the Penman-Monteith $\mathrm{P}-\mathrm{M}$ method (FAO-standard) the FAO-Radiation method were found by Tagliaferre et al. (2010), for the region of Anagé, BA, Brazil, obtaining $\mathrm{R}^{2}=0.84$ and classified as excellent. Moura et al. (2013), working with the estimation of reference evapotranspiration in Rio Grande do Sul State, Brazil, obtained very good performance for the FAORadiation method, corroborating the results of the present study. Costa et al. (2017) obtained similar results in studies conducted in the cities of Palmeira dos Índios, Pão de Açúcar and Maceió, AL, Brazil, with a performance index higher than 0.90 , indicating nearly perfect correlation.

In Figure 3, it is possible to visualize the ETc values that correspond to the water consumption of prickly pear over 152 days of its vegetative development. The highest values occurred in the final phase of the experiment, when plants had higher water consumption due to the higher number of cladodes and also because there was a drought period. With the beginning of the rains of May in the region and rainier days, consequently less solar incidence, the ETc of the crop tended to a decrease, reducing water consumption at the end of the studied cycle.

The highest ETc value (7.11 $\mathrm{mm} \mathrm{d}^{-1}$ ) occurred on April 28, 2015 , a day with high temperature, reaching $34.3^{\circ} \mathrm{C}$. The lowest value found was $1.07 \mathrm{~mm} \mathrm{~d}^{-1}$, recorded on December 18, 2014 (beginning of crop development). During the experimental period, the crop had a consumption of $637.84 \mathrm{~mm}$ with a daily average consumption of $4.22 \mathrm{~mm} \mathrm{~d}^{-1}$, a value close to that found by Pereira et al. (2017), who obtained an average of $5.1 \mathrm{~mm} \mathrm{~d}^{-1}$ working with prickly pear clones in the semiarid region of Pernambuco state, Brazil.

Table 3 shows the crop coefficients obtained daily by the three different empirical methods: Penman-Monteith $\mathrm{Kc}_{(\mathrm{P}-\mathrm{M})}$, Hargreaves-Samani $\mathrm{Kc}_{(\mathrm{H}-\mathrm{S})}$ and $\mathrm{FAO}$-Radiation $\mathrm{Kc}_{(\mathrm{F}-\mathrm{R})}$ for the period of 152 days, at 30-day intervals after planting (DAT).

Table 2. Statistical coefficients of ETo correlation by the methods of Hargreaves-Samani - H-S and FAO-Radiation - F-R with the Penman-Monteith - P-M method

\begin{tabular}{cccccccccc}
\hline $\mathrm{ETO}_{(\mathrm{P}-\mathrm{N})}$ & $\mathbf{S E E}$ & SEE $_{\text {adj }}$ & $\mathbf{a}$ & $\mathbf{b}$ & $\mathbf{R}^{2}$ & $\mathbf{r}$ & $\mathbf{d}$ & $\mathbf{c}$ \\
$\mathrm{ETO}_{(\mathrm{H}-\mathrm{S})}$ & 0.8743 & 0.7906 & 0.4943 & 2.3707 & 0.6022 & 0.7760 & 0.6905 & 0.5358 \\
$\mathrm{ETO}_{(\mathrm{F}-\mathrm{R})}$ & 0.4805 & 0.1542 & 1.1569 & -0.8816 & 0.8479 & 0.9208 & 0.9453 & 0.8705 \\
\hline
\end{tabular}

SEE - Standard error of the estimate; $\mathrm{SEE}_{\text {adj }}$ - Standard error of the estimate adjusted in relation to the linear regression by the standard method; a and $\mathrm{b}$ - Angular and linear coefficients of the determination functions; $r$ - coefficient of correlation; $d$ - Index agreement; $c$ - Performance index

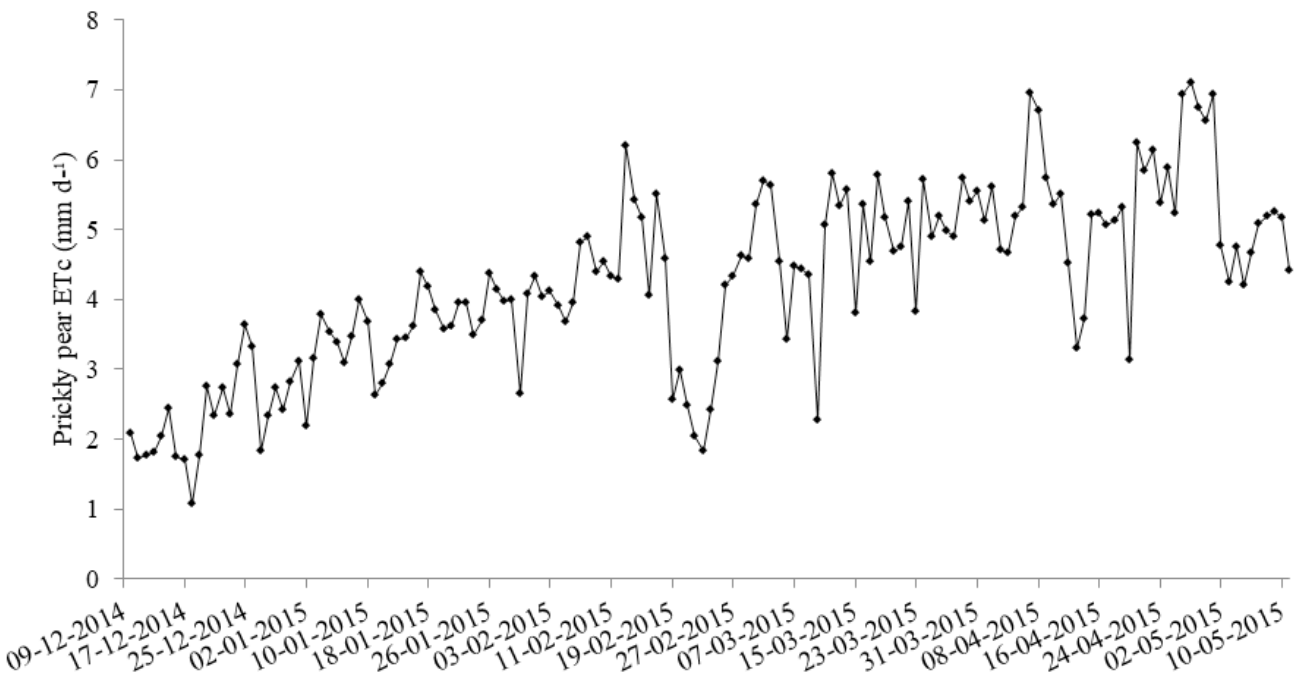

Figure 3. Prickly pear evapotranspiration estimated by drainage lysimeters in the municipality of Arapiraca, AL, Brazil, in the period from December 9, 2014 to May 10, 2015 
Table 3. Prickly pear crop coefficients estimated by the PenmanMonteith - P-M, Hargreaves-Samani - H-S and FAO-Radiation - F-R methods in the period of 150 days after transplanting, at 30-day intervals, in the municipality of Arapiraca, AL, Brazil, in the period from December 9, 2014 to May 10, 2015

\begin{tabular}{cccc}
\hline Days after & \multicolumn{3}{c|}{ Empirical methods } \\
\cline { 2 - 4 } planting & $\mathbf{k C}_{(\mathbf{P}-\mathrm{M}) \mathbf{0})}$ & $\mathbf{k C}_{(\mathrm{H}-\mathrm{S})}$ & $\mathbf{k C}_{(\mathrm{E}-\mathrm{B})}$ \\
\hline $0-30$ & 0.38 & 0.41 & 0.40 \\
$31-60$ & 0.56 & 0.63 & 0.58 \\
$61-91$ & 0.74 & 0.79 & 0.76 \\
$92-122$ & 0.88 & 0.97 & 0.86 \\
$123-152$ & 0.91 & 1.10 & 0.86 \\
\hline
\end{tabular}

It was observed that kc values showed constant increase, which is explained by the constant vegetative growth of the crop. The average kc obtained was $0.69,0.78$ and 0,69 for the P-M, H-S and F-R methods, respectively. Queiroz et al. (2016), working under the conditions of the Pernambuco state, Brazil, with prickly pear clones for the period of one year, obtained an average kc of 0.56 , estimated by soil water balance, a value lower than those found in the present study and closer to those obtained by the methods of Penman-Monteith and FAORadiation, according to Table 3.

\section{Conclusions}

1. Prickly pear had average crop coefficients of $0.69,0.78$ and 0.69 for the methods of Penman-Monteith, HargreavesSamani and FAO-Radiation, respectively, at 152 days of cultivation.

2. During the period of 152 days, the crop evapotranspiration was $637.84 \mathrm{~mm}$, with a daily value of $4.22 \mathrm{~mm} \mathrm{~d}^{-1}$.

\section{Literature Cited}

Allen, R. G.; Pereira, L. S.; Raes, D.; Smith, M. Crop evapotranspiration: Guidelines for computing crop water requirements. Rome: FAO, 1998. 300p. Irrigation and Drainage Paper, 56

Alves, E. S.; Lima, D.F.; Barreto, J. A. S.; Santos, D. P. dos; Santos, M. A. L. dos. Determinação do coeficiente de cultivo para a cultura do rabanete através de lisimetria de drenagem. Irriga, v. 22, p. 194203, 2017. https://doi.org/10.15809/irriga.2017v22n1p194-203

Arruda, E.; Pinna, G. M. M.; Alves, M. Anatomia dos órgãos vegetativos de Cactaceae da caatinga pernambucana. Revista Brasileira de Botânica, v.28, p. 589-601, 2005. https://doi. org/10.1590/S0100-84042005000300015

Bezerra, B. G.; Araújo, J. S.; Pereira, D. D.; Laurentino, G. Q.; Silva, L. L da. Zoneamento agroclimático de palma forrageira (Opuntia sp.) para o estado da Paraíba. Revista Brasileira de Engenharia Agrícola e Ambiental, v.18, p.755-761, 2014. https://doi. org/10.1590/S1415-43662014000700013

Borges Junior, J. C. F.; Anjos, R. J.; Silva, T. J. A.; Lima, J. R. S.; Andrade, C. L. T. Métodos de estimativa da evapotranspiração de referência diária para a microrregião de Garanhuns, PE. Revista Brasileira de Engenharia Agrícola e Ambiental, v.16, p.380-390, 2012. https:// doi.org/10.1590/S1415-43662012000400008

Camargo, A. P.; Sentelhas, P. C. Avaliação do desempenho de diferentes métodos de estimativa da evapotranspiração potencial no Estado de São Paulo, Brasil. Revista Brasileira de Agrometeorologia, v.5, p.89-97, 1997.
Costa, J. A.; Rodrigues, G. P.; Silva, N. D. da; Lopes Sobrinho, O. P.; Costa, L. D. Avaliação de métodos de estimativa da evapotranspiração de referência para Alagoas. Agrometeoros, v.25, n.1, p.173-179, 2017. https://doi.org/10.31062/agrom.v25i1.26277

Doorenbos, J.; Pruitt, W. O. Las necesidades de agua de los cultivos. 5.ed. Rome: FAO,1975. 194p.

Ferreira Junior, R. A.; Souza, J. L.; Teodoro, I.; Campos, A. M. V.; Santos, M. A.; Almeida, A. C. S.; Souza, R. C; Brito, J. E. D.; Silva, P. B.; Costa, C. T. S. Estimativa da evapotranspiração de referência pela radiação solar global na região de Arapiraca-AL. In: Congresso Brasileiro de Meteorologia, 14, 2006, Florianópolis. Anais CBMET, 2006.

Hopkins, W. G. Correlation coefficient: A new view of statistics. 2000. Available on: <http://www.sportsci.org/resource/stats/correl.html $>$. Accessed on: Jan. 2018.

Jensen, M. W.; Burman, R. D.; Allen, R. G. Evapotranspiration and irrigation water requirements. New York: American Society of Civil Engineers, 1995. 329p.

Miranda, W. L.; Carvalho, L. G. de; Castro Neto, P.; Santos, P. A. B. dos. Utilização de lisímetro de drenagem para obtenção de Kc da mamoneira em plantio adensado. Revista Verde de Agroecologia e Desenvolvimento Sustentável, v.11, p. 8-13, 2016. https://doi. org/10.18378/rvads.v11i1.3915

Moura, A. R. C.; Montenegro, S. M. G. L.; Antonino, A. C. D.; Azevedo, J. R. G. de; Silva, B. B. da; Oliveira, L. M. M. de. Evapotranspiração de referência baseada em métodos empíricos em bacia experimental no estado de Pernambuco - Brasil. Revista Brasileira de Meteorologia, v.28, p.181-191,2013. https://doi.org/10.1590/S010277862013000200007

Pereira, A. R.; Villa Nova, N. A.; Sediyama, G. C. Evapo(transpi)ração. Piracicaba: FEALQ, 1997. 183p.

Pereira, P. de C.; Silva, T. G. F da; Zolnier, S.; Morais, J. E. F. de; Santos, D. C. dos. Morfogênese da palma forrageira irrigada por gotejamento. Revista Caatinga, v.28, p.184-195, 2015. https://doi. org/10.1590/1983-21252015v28n321rc

Pereira, P. de C.; Silva, T. G. F. da; Zolnier, S.; Silva, S. M. S. e; Silva, M. J. da. Water balance in soil cultivated with forage cactus clones under irrigation. Revista Caatinga, v.30, p.776-785, 2017. https:// doi.org/10.1590/1983-21252017v30n326rc

Queiroz, M. G.; Silva, T. G. F. da; Zolnier, S.; Silva, S. M. S. e; Souza, C. A. A. de; Carvalho, H. F. de S. Relações hídrico-econômicas da palma forrageira cultivada em ambiente semiárido. Irriga, v.edição especial, p.141-154, 2016. https://doi.org/10.15809/ irriga.2016v1n01p141-154

Souza, A. P. de; Pereira, J. B. A.; Silva, L. D. B. da; Guerra, J. G. M.; Carvalho, D. F. de. Evapotranspiração, coeficientes de cultivo e eficiência do uso da água da cultura do pimentão em diferentes sistemas de cultivo. Acta Scientiarum Agronomy. v.33, p.15-22, 2011. https://doi.org/10.4025/actasciagron.v33i1.5527

Tagliaferre, C.; Silva, R. A. de J.; Rocha, F. A.; Santos, L. da C.; Silva, C. dos S. da. Estudo comparativo de diferentes metodologias para determinação da evapotranspiração de referência em Eunápolis BA. Revista Caatinga, v.23, p.103-111, 2010.

Willmott, C. J.; Ackleson, S. G.; Davis, R. E.; Feddema, J. J.; Klink, K. M.; Legates, D. R.; O’Donnell, J.; Rowe, C. M. Statistics for the evaluation and comparison of models. Journal of Geophysical Research, v.90, p.8995-9005, 1985. https://doi.org/10.1029/JC090iC05p08995

Xavier, R. A.; Dornellas, P. da C. Análise do comportamento das chuvas no município de Arapiraca, região Agreste de Alagoas. Revista Geografia, v.14, p.49-64, 2010. 